\title{
Granulometric Analysis of Rajmahal Inter-Trappen Sedimentary Rocks (Early Cretaceous), Eastern India, Implications for Depositional History
}

\author{
Aparna Sinha, Sarwar Rais \\ Department of Geology, Aligarh Muslim University, Aligarh, India \\ Email: aparna.sinha.bhu@gmail.com
}

How to cite this paper: Sinha, A. and Rais, S. (2019) Granulometric Analysis of Rajmahal Inter-Trappen Sedimentary Rocks (Early Cretaceous), Eastern India, Implications for Depositional History. International Journal of Geosciences, 10, 238-253. https://doi.org/10.4236/ijg.2019.103015

Received: May 22, 2018

Accepted: March 17, 2019

Published: March 20, 2019

Copyright (c) 2019 by author(s) and Scientific Research Publishing Inc. This work is licensed under the Creative Commons Attribution International License (CC BY 4.0).

http://creativecommons.org/licenses/by/4.0/

\begin{abstract}
Rajmahal trap along with its Inter-trappean sedimentary rocks is found exposed in the eastern part of India $\left(24^{\circ} 00^{\prime} \mathrm{E}-25^{\circ} 15^{\prime} \mathrm{N} ; 87^{\circ} 20^{\prime} \mathrm{E}-87^{\circ} 15^{\prime} \mathrm{E}\right)$. Ten representative samples of Inter-trappean sandstone selected from the study area have been subjected to granulometric analysis. The result of the grain size analysis indicates that these sandstone specimens are very fine to fine grained with unimodal grain size distribution. They are dominantly fine skewed and generally mesokurtic in nature. The linear discriminant function plots of various grain size parameters suggest that these sandstones appear to have been deposited either in shallow marine or lacustrine environment. On multigroup multivariate discriminant functions V1 - V2 diagram majority of the samples fall in the beach depositional environment, indicating that most of the sediments were reworked by wave processes before deposition. The $\mathrm{C}-\mathrm{M}$ pattern diagram shows that the sediment deposition took place in beach environment by rolling or suspension of sediments; hence the clastics were deposited in low energy condition.
\end{abstract}

\section{Keywords}

Rajmahal Inter-trappeans, Early Cretaceous, Granulometric Analysis, Depositional History

\section{Introduction}

Grain size is the most fundamental feature and important descriptive property of siliciclastic rocks. Granulometric properties have been widely employed to decipher the depositional history, mainly depositional environment and process, 
hydrodynamic conditions and transportation mechanism and also provide clues about the provenance [1] [2] [3] [6].

Rajmahal volcanic rocks of Early Cretaceous age are part of Upper Gondwana Group. These volcanics along with Inter-trappean strata occur in eastern parts of Eastern Indian Shield [5] [6] [34]. At places these lava flows rest conformably over rocks of Dubrajpur Formation (Upper Triassic to Lower Jurassic) and also occasionally rest unconformably over Barakar Formation (Permian); however at a few localities Precambrian rocks form the basement for these volcanics. Only lower one-third part of Rajmahal lava contains Inter-trappean beds whereas upper two-thirds of the rock succession consists of subaerial fine grained basalt without any Inter-trappean beds [7]. These Inter-trappeans are made up of both clastic and volcanoclastic rocks. The clastic rocks occur in the form of thin or thick [7] beds of sandstone, black or grey shale/mudstone and lenses and pockets of bentonite, pyroclasts and oolites [7].

In the present study an attempt has been made to undertake a detailed grain size analysis of ten Inter-trappeans and stone samples selected from northern part of the Rajmahal basin (Figure 1), where exposure of these rocks is comparatively

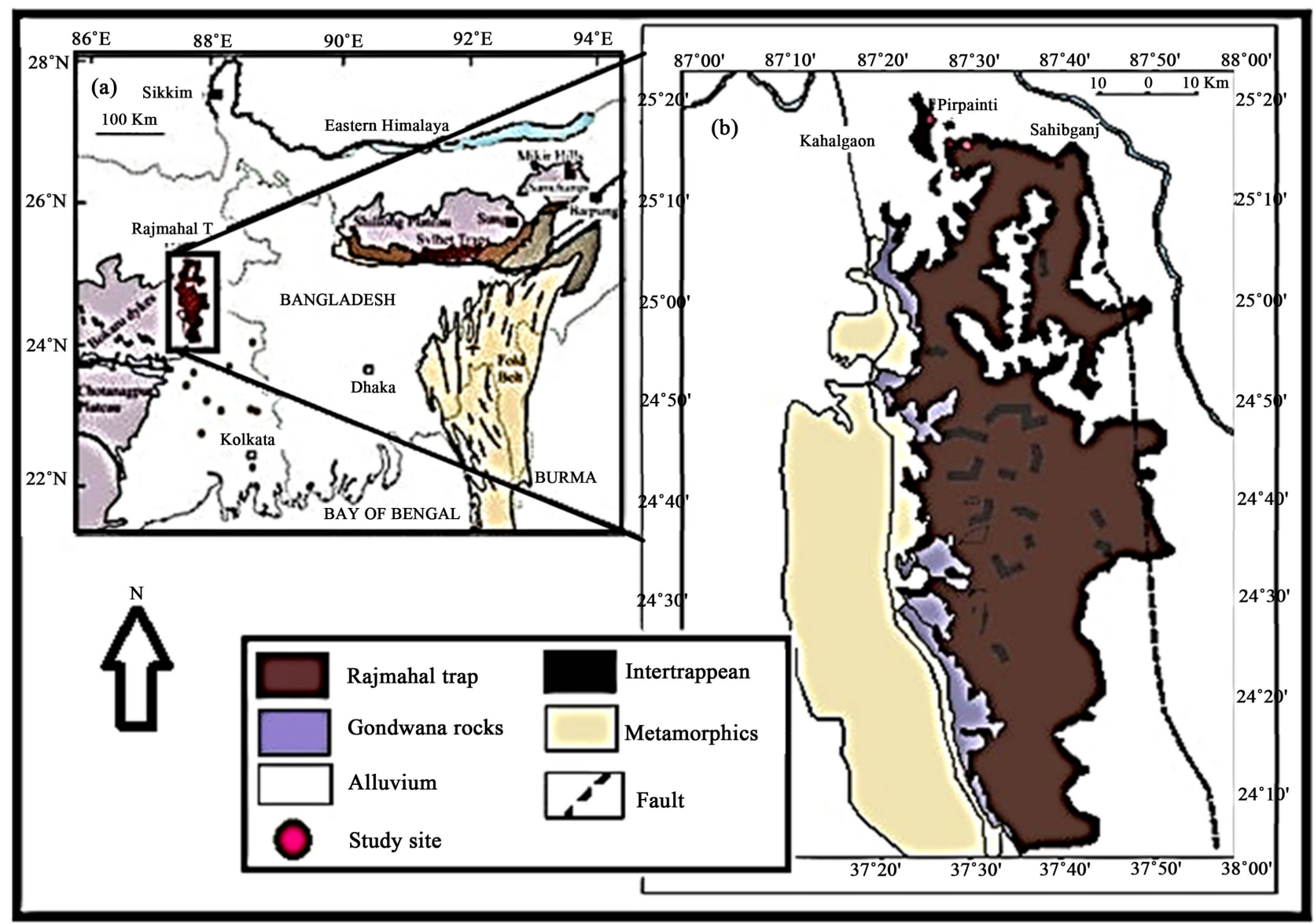

Figure 1. (a) Location of Rajmahal volcanic province(Rajmahal traps) and geological features of eastern shield; (b) Geological map of Rajmahal basin (after Ghose and Kent 2003) showing the areal extent of trap rocks, major boundary fault, Inter-trappean rocks and location of study sites. 
better. Statistical parameters like graphic mean, graphic standard deviation, skewness and kurtosis have been calculated. The data thus generated have been employed to understand the nature of these clastic sediments. Various bivariate plots have been utilized to constrain pattern of sedimentation and depositional environment.

\section{Geological Setting}

The Rajmahal Volcanic Province is a N-S trending elongate belt located in the parts of Eastern India. These volcanic rocks along with Inter-trappeans cover an area of about $4300 \mathrm{sq} \mathrm{km}$ between latitudes $24^{\circ} 00^{\prime}-25^{\circ} 15^{\prime}$ and longitudes $87^{\circ} 20^{\prime}$

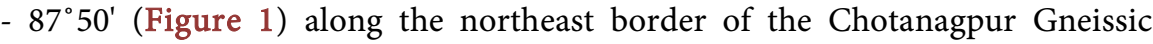
Complex [8] [9]. Along NW side of the Rajmahal basin Chotanagpur Gneissic Complex (Precambrian) is present and towards western margin lays the alluvium (Quaternary) of Bengal basin. Rajmahal basin is bounded by N-S trending normal faults on both the eastern as well as the western margins leading to exposure of Lower Gondwana rocks in the western part of the basin. General stratigraphy of Rajmahal basin consist of Lower Gondwanas which commence with Talchir Formation (Carboniferous) followed by Barakar Formation (Permian), the Upper Gondwana sequence is represented by Dubrajpur Formation (Upper Triassic) and Rajmahal Formation (Rajmahal trap along with Inter-trappean beds) and Recent alluvium. The Rajmahal basin consists of a number of volcanic flows and associated Inter-trappean strata. About fifteen surface flows and twenty eight subsurface lava flows have been identified [11]. [12] documented that stratigraphic thickness of volcanic succession is $600 \mathrm{~m}$ and total thickness of Inter-trappean sedimentary beds is $<35 \mathrm{~m}$. These Inter-trappean beds consist of sandstones, siltstones, white and grey colored (baked) shales, arenaceous clay, carbonaceous shales, pockets and lenses of bentonite, volcanoclastic rocks and oolites. This magmatic activity widely considered as a result of lithospheric interaction of Kerguelen plume during separation of India and Australia-Antarctica in the process of fragmentation of Gondwanaland between 165 - $133 \mathrm{ma}$ [6] [15] [16] [17] [18].

\section{Material and Methods}

The Inter-trappean strata is severely dismembered due to haphazard mining in the study area. Therefore great care has been taken in collection of sandstones samples during the field work out of thirty five only ten representative sandstone samples have been selected for grain size analysis. For classification of various classes of easily grain size conventional sieving technique (20) has been adopted. The selected sandstone samples were disaggregated. The carbonate and organic matter coating on the grain surfaces were removed by treating with $10 \%$ dilute hydrochloric acid and 6\% hydrogen peroxide respectively. Samples were then washed with distilled water and oven dried. Finally 100 grams of the each loose sample were selected and subjected to conventional sieving process. The sieves 
were arranged on phi intervals starting from 22 meshes $(0.35 \varphi), 30$ mesh $(0.75 \varphi), 44$ mesh $(1.50 \varphi), 66$ mesh $(2.00 \varphi), 85$ mesh $(2.60 \varphi), 120$ mesh $(3.0 \varphi)$, 170 mesh $(3.50 \varphi)$ and 240 mesh $(4.10 \varphi)$. This set of sieves was shaken for at least thirty minutes by electrically operated shaker for proper separation of each grade. The grains retained by each sieve were taken, weighed and weight percentage calculated.

On the basis of weight percentage data cumulative curves (Figure 2) were prepared, which act as a basic tool in calculating statistical parameters. Using these cumulative curves various grain parameters were calculated as proposed by [21]. Bivariate plots have been used to understand the depositional setting of these Inter-trappean sandstone samples. Linear discriminant function [26] is used to interpret and distinguish process and environment of deposition. C-M plot of Passega [25] is employed to constrain different depositional processes, mechanism of sedimentation and energy level of the transporting medium.

\section{Results and Discussion}

\subsection{Grain Size Parameters}

Using equations as proposed by (21) (Table 1) (Graphic mean, Inclusive standard deviation, Inclusive graphic skewness and Kurtosis) were computed (Table 2). These statistical grain parameters are discussed in the following paragraphs:

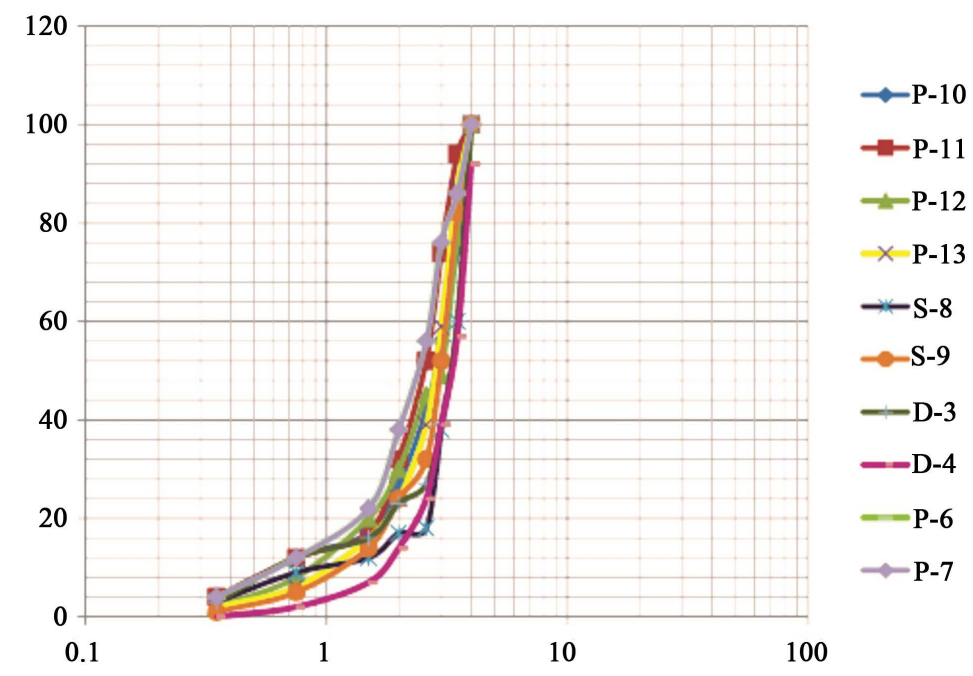

Figure 2. Cumulative frequency curve.

Table 1. Formulas for calculating grain size statistical parameters given by Folk and Ward (1957) to study the characteristics of sediments.

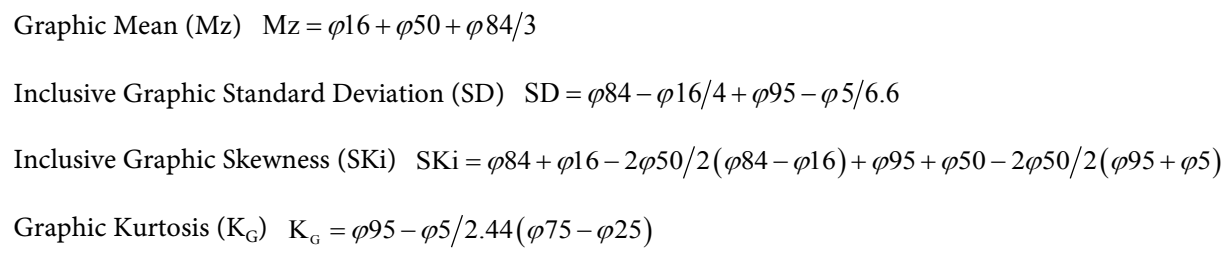


Table 2. Grain size parameters of Inter-trappean sandstone samples of Rajmahal formation.

\begin{tabular}{ccccccc}
\hline S. No. & Mz & Sd & Sk & Kg & C & M \\
\hline P-11 & 2.4 & 1.21 & 0.13 & 0.84 & 810 & 210 \\
P-12 & 2.4 & 0.67 & 0.27 & 1.23 & 820 & 165 \\
P-13 & 2.63 & 1.05 & 0.11 & 0.79 & 810 & 177 \\
P-14 & 2.43 & 0.87 & 0.14 & 1.06 & 800 & 198 \\
S-8 & 2.57 & 0.95 & 0.06 & 1.22 & 820 & 177 \\
S-9 & 2.6 & 1.02 & 0.17 & 1.11 & 770 & 186 \\
D-3 & 2.77 & 0.98 & 0.16 & 0.68 & 790 & 165 \\
D-4 & 2.57 & 1.03 & 0.24 & 1.09 & 780 & 198 \\
P-7 & 2.47 & 0.86 & 0.16 & 0.9 & 780 & 198 \\
P-8 & 2.43 & 1.04 & 0.23 & 1.06 & 820 & 186 \\
\hline
\end{tabular}

\subsubsection{Graphic Mean Size (Mz)}

Graphic Mean size mainly gives an idea about overall size of grains of the Clastic rocks. The maximum and minimum value of the studied samples has been analyzed and summarized (Table 2). The values of the mean size for Rajmahal Inter-trappean sandstones range between $2.77 \varphi$ to $2.24 \varphi$ (Figure $3(\mathrm{a})$ ). The average mean size value $(2.62 \varphi)$ of the studied sandstone samples exhibit the dominance of fine grained sand with minor variation in the grain size. These slight variations in the mean size value suggest fluctuation in the energy level in the basin during sedimentation process within the basin. However the dominance of fine grained sediments in the Inter-trappean sandstone samples indicates low energy condition during the deposition of Rajmahal Inter-trappean sandstones.

\subsubsection{Inclusive Graphic Standard Deviation ( $\left.\sigma_{1}\right)$}

The degree of sorting or uniformity of grain size distribution is measured by the inclusive standard deviation. These character of sediments help in explaining hydrodynamic regime of depositional basin. The standard deviation values of the Rajmahal Inter-trappean sandstones range from $0.67 \varphi$ to $1.21 \varphi$ (Table 2). This implies that the sandstones are moderately to poorly sorted. Fifty percent of the populations from the selected samples are moderately sorted with values ranging between $0.67 \varphi$ to $0.98 \varphi$ and remaining fifty percent of these sandstones show poor sorting with value ranging from $1.02 \varphi$ to $1.21 \varphi$ (Figure 3(b)). Sandstones having moderate sorting represent that this may be due to occasional winnowing action of depositing agent, whereas poor sorting of sediments is an indicator of absence of winnowing activity perhaps due to very low energy level of depositing agent. The standard deviation values of these Inter-trappean sediments show that perhaps the energy level of depositing medium fluctuated slightly from time to time. 


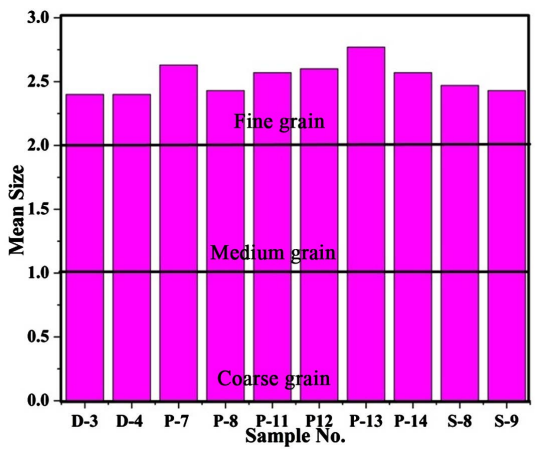

(a)

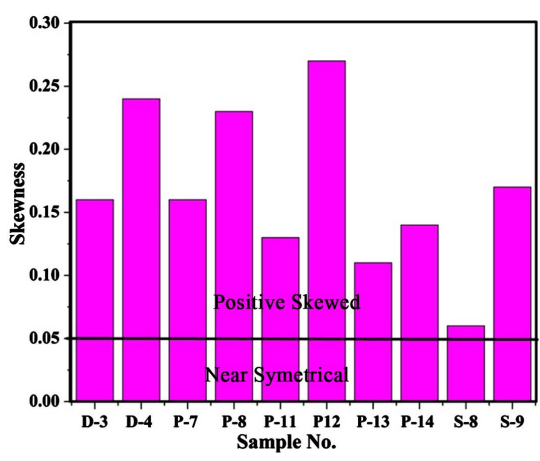

(c)

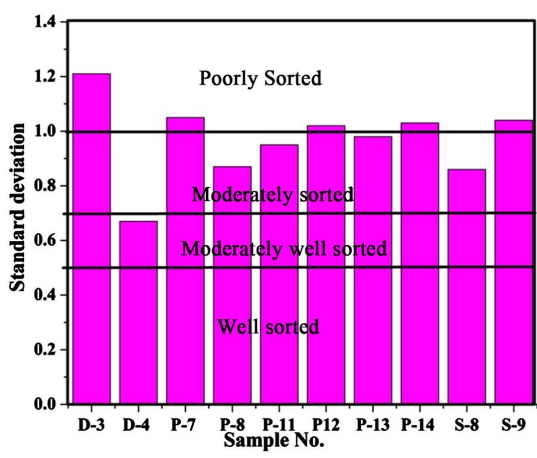

(b)

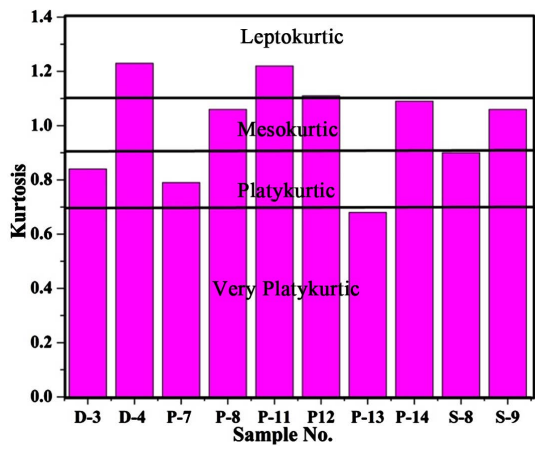

(d)

Figure 3. Grain Size parameter (graphic mean, inclusive standard deviation, inclusive graphic skewness and graphic Kurtosis) of Rajmahal Inter-trappean sandstones.

\subsubsection{Inclusive Graphic Skewness ( $\left.\mathrm{SK}_{1}\right)$}

The graphic skewness measures symmetry of grain size distribution i.e. dominance of coarse or fine grained sediments in the tails of cumulative curve. Negative graphic skewness value point's dominance of coarse grained sediments in the tail, whereas positive values indicate more fine grained material in the tail of the curve. The skewness values of the analyzed samples range from 0.06 to 0.27 (Table 2), thus the Inter-trappean sandstone samples are near symmetrical to finely skewed in nature (Figure $3(\mathrm{c})$ ). Out of ten, nine sandstone are finely skewed. Only one sample collected from Sankarpahar area exhibit near symmetrical distribution of grains. The dominance of fine skewed nature of these Rajmhal Inter-trappean sandstone samples indicate that these sandstones may have been deposited in the low energy condition.

\subsubsection{Graphic Kurtosis $\left(\mathrm{K}_{\mathrm{G}}\right)$}

Kurtosis measures the ratio between sorting in the extremes of the distribution compared with sorting in the central part of the curves. It denotes peakedness of the curve. The kurtosis values of the investigated Inter-trappean sandstone samples range from 0.68 to 1.22 (Table 2). Majority of the studied sandstone samples are mesokurtic in nature and values range from 0.9 to 1.11 (Figure 3(d)), whereas kurtosis data of three samples range from 0.68 to 0.84 . So they are classified as platykurtic and only two samples have kurtosis values are 1.22 and 1.23, therefore, they are leptokurtic in nature (Figure 3(d)). This variation in kurtosis 
values may be due to occasional variation in the flow characteristic of the depositional medium.

\subsection{Bivariate Plots of Statistical Parameters}

The inter-relationship between different statistical parameters of grain size of the clastic rocks helps to understand nature of sediments, depositional setup and energy level of depositional agent [21] [27] [33] [35] [36]. These bivariate plots between various grain size parameters are very helpful to differentiate especially between fluvial, coastal and eolian depositional environments. Considering the significance of such plots in sedimentological studies, these interrelationships have been applied in the present study.

The plot between mean and standard deviation values (Figure 4(a)) of the studied inter-trappean sandstone samples show clustering show clustering of values close to end point of inverted "V" shape as proposed by [21]. This suggests the dominance of fine to very fine grained and moderately to poorly sorted sand grains. The distribution of sediments is nearly unimodal. Both mean grain size and sorting are hydraulically controlled properties of clastic sediments. The sinusoidal curve of mean and skewness attributes [21] is due to proportional mixture of two size classes of sediments. Ideally it is near symmetrical but depending upon the proportionality of the size class of the sediments it gives negative or positive skewness accordingly. The values of selected sandstone samples fall dominantly along positively skewed part of the graph (Figure 4(b)), hence it is very clear that the studied sediments are unimodal in nature and deposited in constant energy conditions.

The bivariate plot of mean vs. kurtosis consists of two or more class size of sediments that affects the index of kurtosis, The relationship between two sediment attributes is highly complex and theoretical [21]. In the interrelation plot of their mean vs kurtosis (Figure 4(c)) the points cluster close to the base of the modal graph. There is varying proportion of fine grained sand mixed with very fine sand to silt has been noted in these sandstone samples. This nature of the sediments reduces the degree of sorting, mainly in the tail portion of the curve. Thus, these Rajmahal Inter-trappean sandstone samples are platykurtic to leptokurtic in nature.

The modal graph of skewness vs. standard deviation [21] produces a scattered trend in the form of nearly circular ring. The reason behind this scattering may be either unimodal distribution in with good sorting or equal mixture of two modes. The present scattering shows clustering of grains in one sector (Figure 4(d)). This shows the dominance of fine grained sand mixed with very fine sand or silt leading to slight deviation in the skewness in the studied Rajmahal Inter-trappean sandstone samples. The plot of skewnessvs kurtosis given by [21] follows a regular sinusoidal path, as the value of mean changes and depends upon two modes. The present calculated values fall towards one side of the graph which shows dominance of fine sand with increasing very fine sand to silt size grains (Figure $4(\mathrm{e})$ ). The plot between kurtosis and standard deviation 


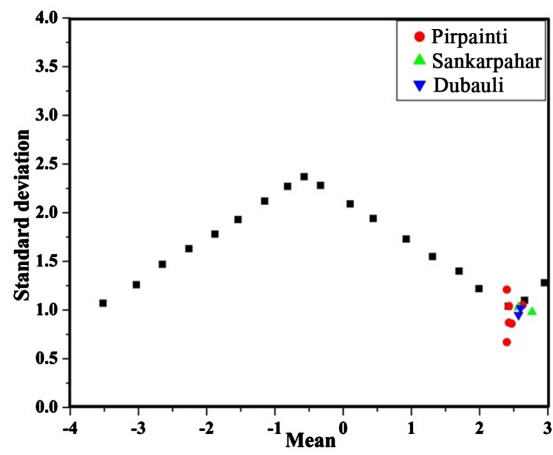

(a)

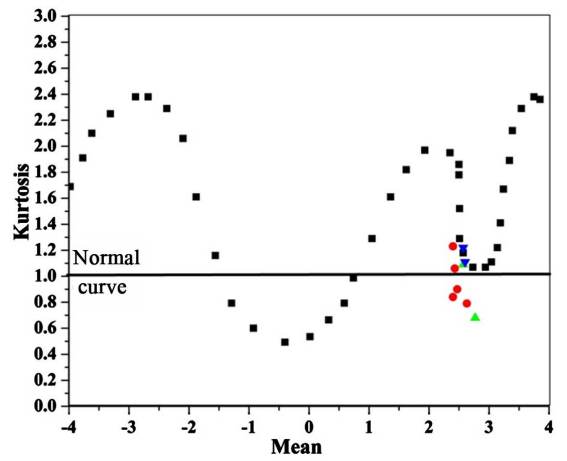

(c)

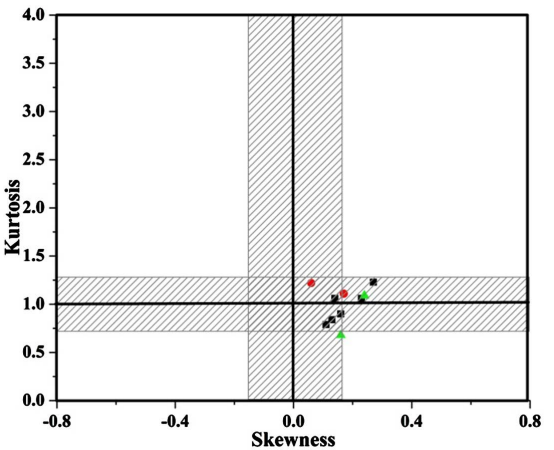

(e)

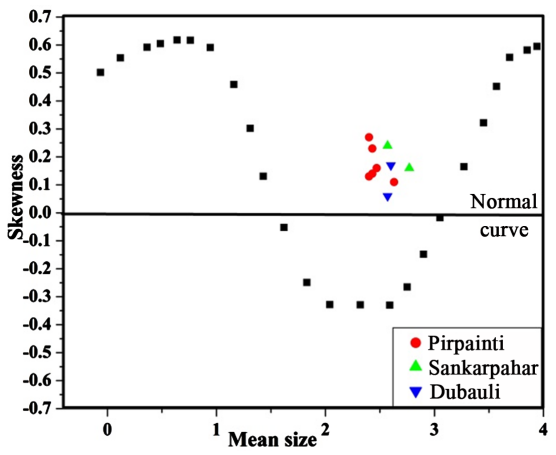

(b)

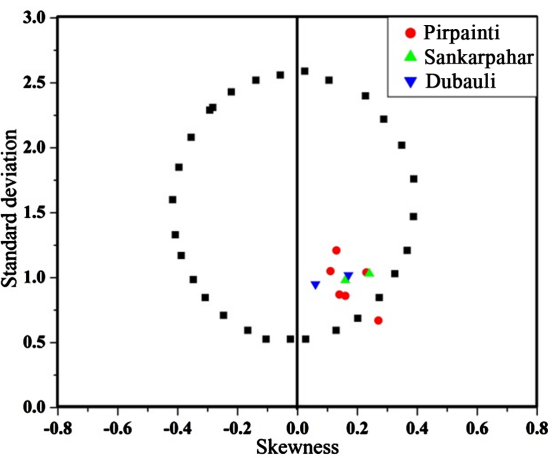

(d)

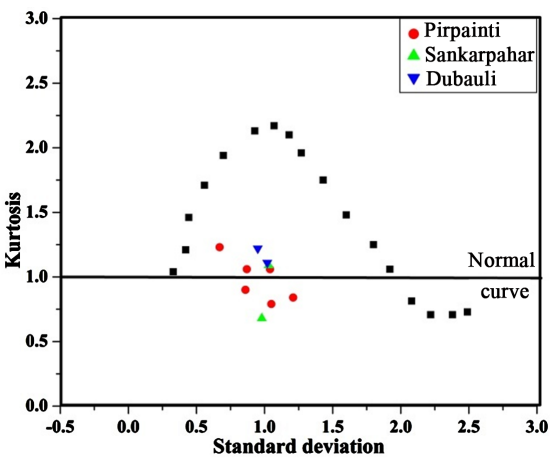

(f)

Figure 4. Bivariate plot showing the selected samples in model plots proposed by Folk \& Ward (1957): (a) mean vs standard deviation; (b) mean vsskewness; (c) mean vs kurtosis; (d) skewnessvs standard deviation; (e) skewnessvs kurtosis; (f) kurtosis vsstandard deviation.

(Figure 4(f)) shows variation in kurtosis of the studied samples but dominantly they are mesokurtic in nature and moderate sorting.

\section{Depositional Environment}

\subsection{Linear Discriminate Function}

To decipher the depositional environment of Rajmahal Inter-trappean sandstones, the equations proposed by (26) have been employed in the present investigation.

Equation (1) is applied to distinguish between shallow agitated water and 
beach environment of deposition.

$$
\mathrm{Y} 1=-3.5688 \mathrm{M}+3.7016 \mathrm{SD}^{2}-2.0766 \mathrm{SK}+3.1135 \mathrm{KG}
$$

Depositional value of $\mathrm{Y} 1<-2.7411$ indicates shallow agitated water environment and in case the value is more than -2.7411 it suggests beach environment. In the present study Y1 value ranges from -3.63 to 0.8 , (Table 3 ) suggesting the half number of these sandstones were laid down in shallow agitated water, whereas remaining fifty percent samples shows deposition in beach environment (Figure 5(a)).

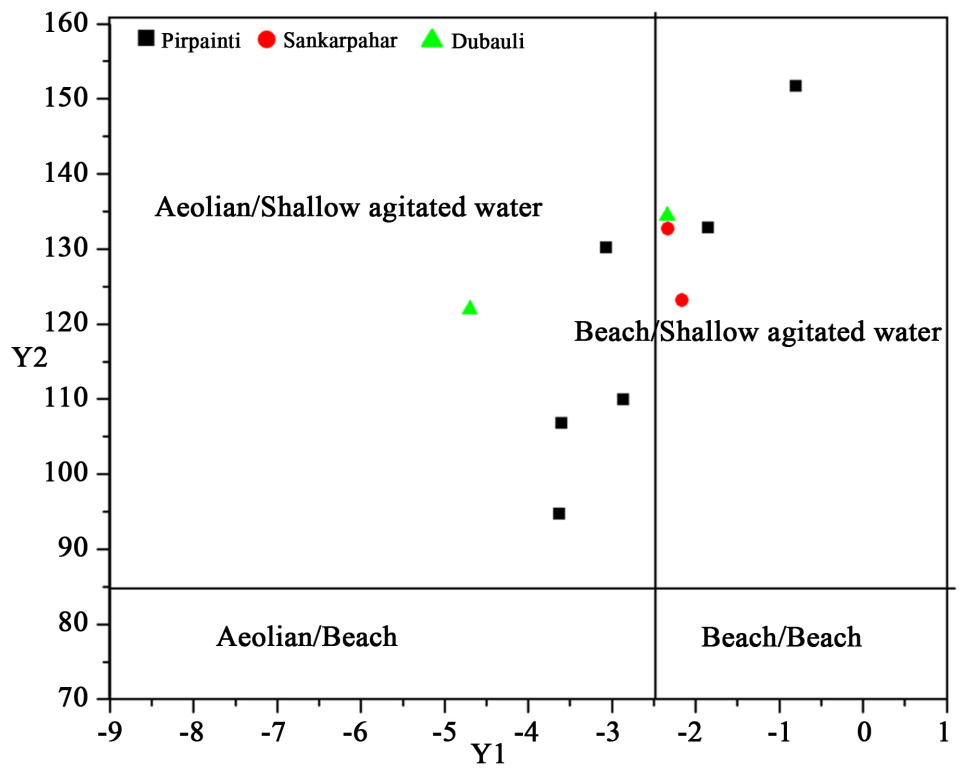

(a)

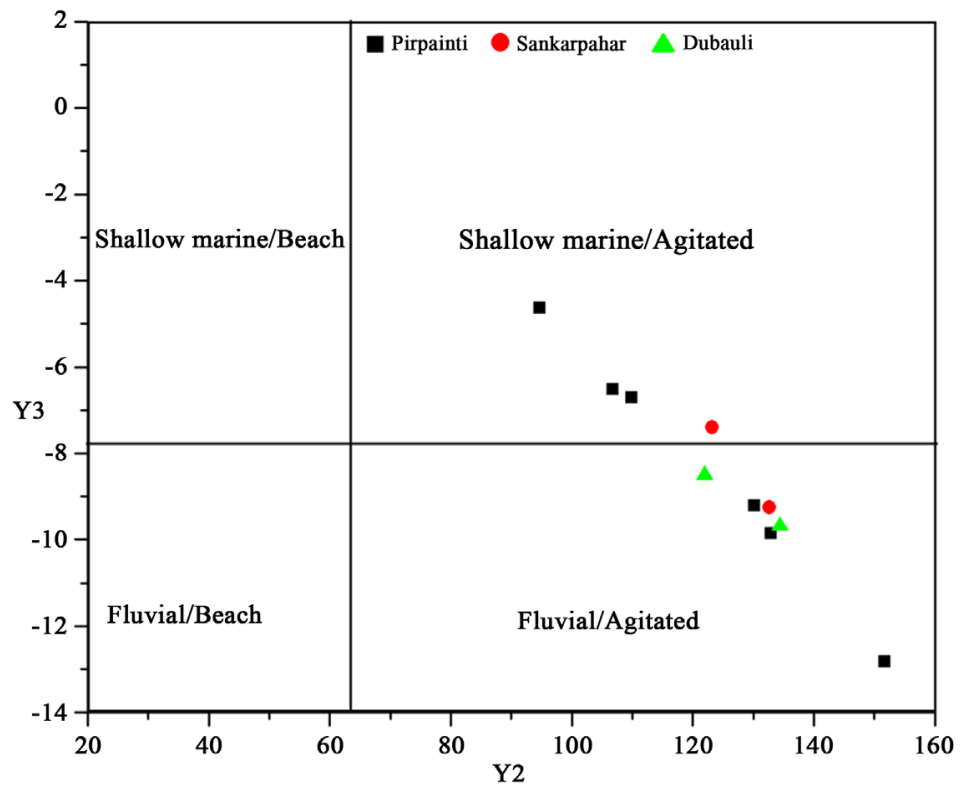

(b)

Figure 5. Discrimation plots of environment based on linear discriminant function as given by (34): (a) Y1 vs Y2; (b) Y2 vs Y3. 
Table 3. Linear discriminant function and depositional environment of Inter-trapean beds.

\begin{tabular}{|c|c|c|c|c|c|c|}
\hline \multicolumn{4}{|c|}{ Discriminant function } & \multicolumn{3}{|c|}{ Depositional environment } \\
\hline S. No. & $\mathrm{Y} 1$ & $\mathrm{Y} 2$ & Y3 & $\mathrm{Y} 1$ & $\mathrm{Y} 2$ & $\mathrm{Y} 2$ \\
\hline P-11 & -0.8 & 151.66 & -12.83 & $\begin{array}{c}\text { Shallow } \\
\text { Agitated Water }\end{array}$ & Shallow Marine & Lacustrine \\
\hline $\mathrm{P} 12$ & -3.63 & 94.71 & -4.62 & Beach & Shallow Marine & Shallow Marine \\
\hline P-13 & -3.07 & 130.22 & -9.21 & Beach & Shallow Marine & Lacustrine \\
\hline P-14 & -2.86 & 109.91 & -6.7 & Beach & Shallow Marine & Shallow Marine \\
\hline S-8 & -2.16 & 123.18 & -7.4 & $\begin{array}{c}\text { Shallow } \\
\text { Agitated Water }\end{array}$ & Shallow Marine & Shallow Marine \\
\hline S-9 & -2.33 & 132.67 & -9.25 & $\begin{array}{c}\text { Shallow } \\
\text { Agitated Water }\end{array}$ & Shallow Marine & Lacustrine \\
\hline$D-3$ & -4.7 & 121.94 & -8.5 & Beach & Shallow Marine & Lacustrine \\
\hline$D-4$ & -2.34 & 134.45 & -9.68 & $\begin{array}{c}\text { Shallow } \\
\text { Agitated Water }\end{array}$ & Shallow Marine & Lacustrine \\
\hline$P-7$ & -3.6 & 106.79 & -6.52 & Beach & Shallow Marine & Shallow Marine \\
\hline P-8 & -1.85 & 132.88 & -9.85 & $\begin{array}{c}\text { Shallow } \\
\text { Agitated Water }\end{array}$ & Shallow Marine & Lacustrine \\
\hline
\end{tabular}

Equation (2) was used to distinguish between beach and shallow marine environment

$$
\mathrm{Y} 2=15.6534 \mathrm{M}+65.7091 \mathrm{SD}^{2}+18.1071 \mathrm{SK}+18.5043 \mathrm{KG}
$$

The value of $\mathrm{Y} 2$ is $<-63.3650$, is an indication of beach environment otherwise depositional environment is shallow marine if the value of $\mathrm{Y} 2$ is $>63.3650$. In the present investigation Y2 values ranges from 134.45 to 94.71 (Table 3). Thus suggesting that deposition of these sandstones took place in shallow marine condition.

To discriminate between shallow marine and lacustrine environment of deposition Equation (3) was applied:

$$
\mathrm{Y} 3=0.2852 \mathrm{M}-8.7604 \mathrm{SD}^{2}-4.8932 \mathrm{SK}+0.0482 \mathrm{KG}
$$

In case value of $\mathrm{Y} 3$ is $>-7.4190$ then the environment of deposition is shallow marine and if the $\mathrm{Y} 3$ is lesser than -7.4190 suggest deposition in lacustrine environment. The result of $\mathrm{Y} 3$ equation for the studied sandstone samples ranges between -12.83 to -4.62 (Table 3 ) indicating deposition of these sediments took place in shallow marine and laustrine environment.

Where M, SD, SK and KG represents mean grain size, standard deviation, skewness and kurtosis respectively.

The binary plots between Y1 and Y2 after (34) show that all the samples of the Rajmahal Inter-trappean deposits fall in the beach/shallow marine environment (Figure 5(a)). Plot between Y2 and Y3 (Figure 5(b)) show that most of the samples fall in shallow marine/agitated environment. Hence from the plots of 
linear discriminant function it is concluded that the sediments of Rajmahal Inter-trappeans and stones has been deposited under marine environment in shallow water condition.

\subsection{Multigroup Multivariant Discriminant Functions}

Multigroup multivariant discriminant function as proposed by [20] was applied for deciphering the depositional environment of Rajmahal Inter-trappean sandstone beds. This discriminant function uses all the four statistical grain size parameters proposed by [21]. Sahu in (1983) applied this discriminant analysis to obtain the Eigen vector V1 and V2 and determined the depositional environment. Following equations are used to calculate V1 and V2:

$$
\begin{aligned}
\mathrm{V} 1 & =0.48048 \mathrm{Mz}+0.06231 \mathrm{SD}+0.40602 \mathrm{Sk}+0.44413 \mathrm{Kg} \\
\mathrm{V} 2 & =0.24523 \mathrm{Mz}-0.45905 \mathrm{SD}+0.15715 \mathrm{Sk}+0.83931 \mathrm{Kg}
\end{aligned}
$$

where $\mathrm{Mz}=$ Mean; $\mathrm{SD}=$ Standard Deviation; Sk = Skewness and $\mathrm{Kg}=$ Kurtosis.

The value of $\mathrm{V} 1$ ranges between 1.54 to 1.8 and value of $\mathrm{V} 2$ ranges from .72 to 1.27 (Table 4). Plot has been made by between V1 vs V2 (Figure 6). The values of majority of the studied sandstone samples fall in the field of beach environment in the plot of multivariant discriminant diagram (Figure 6).

\subsection{Bivariate Plots}

In sedimentological studies bivariate plot uses different statistical parameters which help in understanding the depositional environments. Several authors have discussed importance of grain size analysis in clastic rocks inpaleo environmental reconstruction [30] [33]. Using the statistical parameters of grain size bivariate plots between skewnessvs standard deviation and skewnessvs mean size were prepared (Figure 7(a) and Figure 7(b)). The plots reveal that the studied Rajmhal Inter-trappean sediments were deposited by wave processes in beach and island milieu.

Table 4. V1 and V2 data of Rajmahal inter-trappean sandstones.

\begin{tabular}{ccc}
\hline S. No. & V1 & V2 \\
\hline P-11 & 1.65 & 0.76 \\
P-12 & 1.85 & 1.36 \\
P-13 & 1.72 & 0.84 \\
P-14 & 1.75 & 1.11 \\
S-8 & 1.86 & 1.23 \\
S-9 & 1.87 & 1.13 \\
D-3 & 1.76 & 0.83 \\
D-4 & 1.88 & 1.11 \\
P-7 & 1.71 & 0.99 \\
P-8 & 1.80 & 1.04 \\
\hline
\end{tabular}




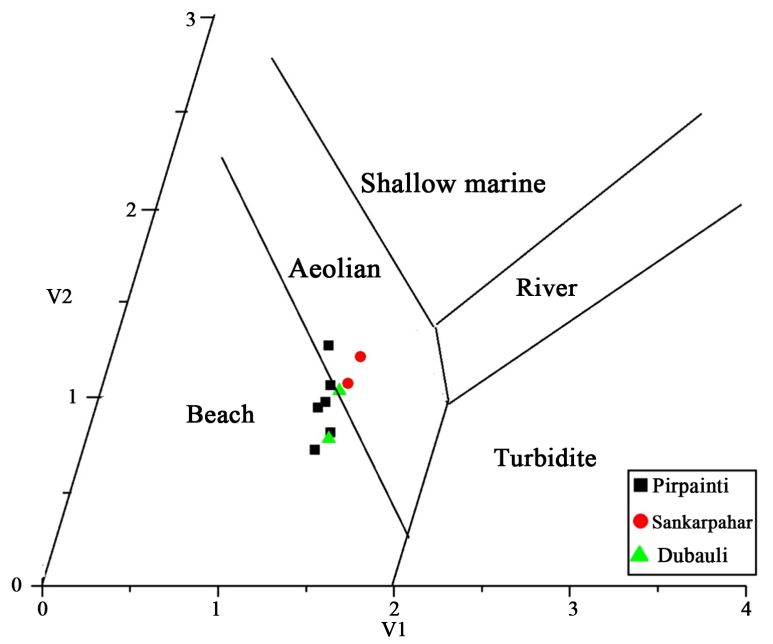

Figure 6. Multivariant discriminant plot.

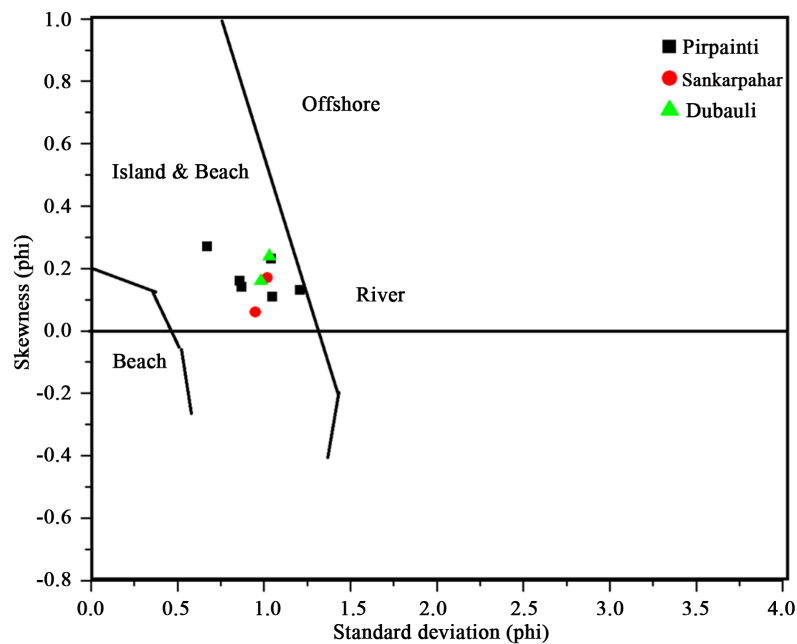

(a)

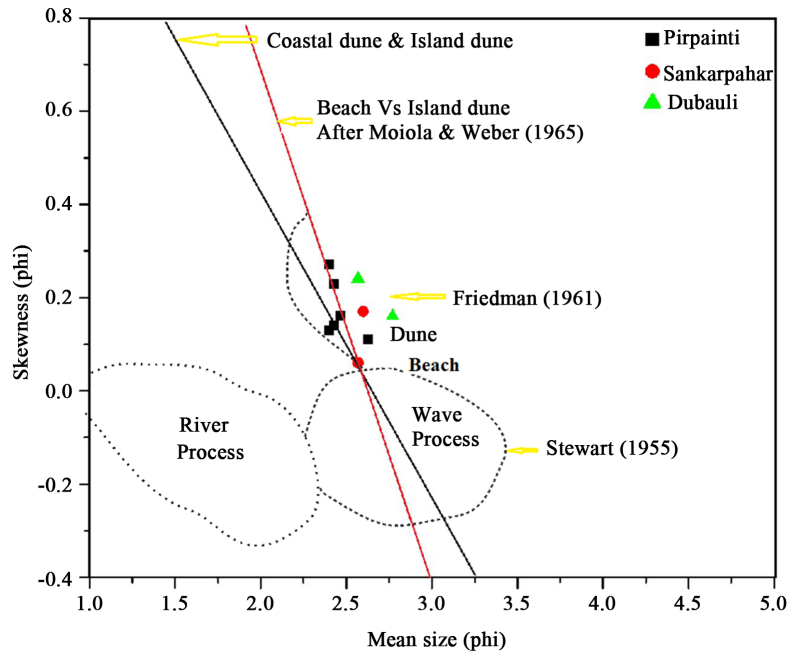

(b)

Figure 7. Bivariate plot: (a) Standard deviation vs skewness; (b) Mean size vs skewness of Rajmahal Inter-trappean sandstone. 


\subsection{Passega Diagram (CM Pattern)}

C-M plot was introduced as an important tool to decipher the hydrodynamic forces that works during deposition of sediment [27]. This is a binary plot that marks the relation between coarser one percentile values (C) in micron against the median value $(\mathrm{M})$ in micron on a log probability scale (Table 2). This relationship between $\mathrm{C}$ and $\mathrm{M}$ helps to decipher the nature of sediment types and energy of transporting medium [27] [33]. In the present study the values of C against $\mathrm{M}$ (Table 2) were plotted on the Passega diagram. The result shows that all the samples of Rajmahal Inter-trappeans and stone fall in III sector between $\mathrm{P}-\mathrm{Q}$ regions (Figure 8) which depict that these sediments were deposited by the process of rolling and suspension. The C-M plot (Figure 9) indicates that the studied Rajmahal Inter-trappean clastic sediments were perhaps deposited by turbidity currents.

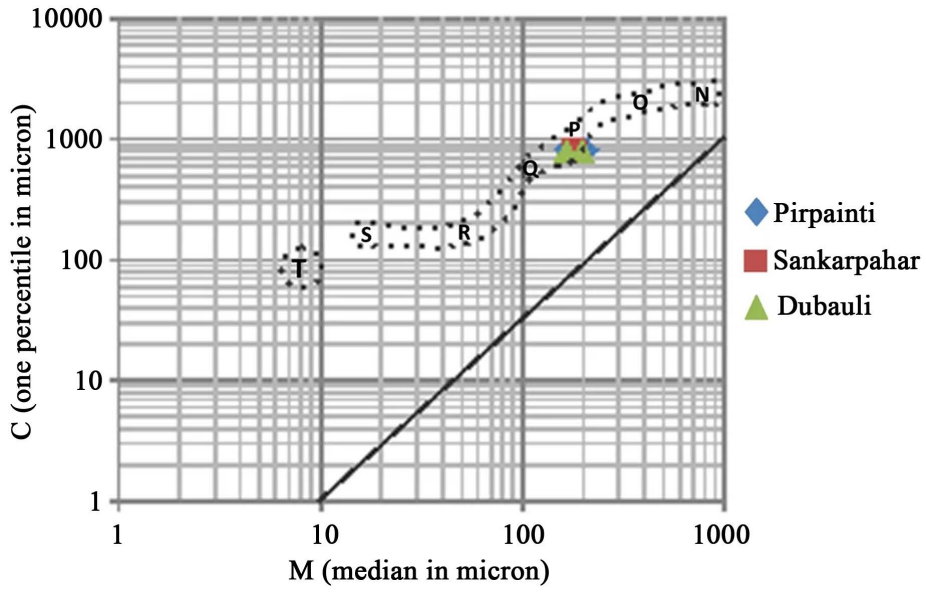

Figure 8. C-M plot showing the transporting mechanism of the Rajmahal Inter-trappean sandstones. Rolling (NO); Rolling \& suspension (OP); Suspension \& rolling (PQ); Graded suspension, mainly saltation (QR); Uniform suspension (RS); Pelagic suspension $(\mathrm{T})$

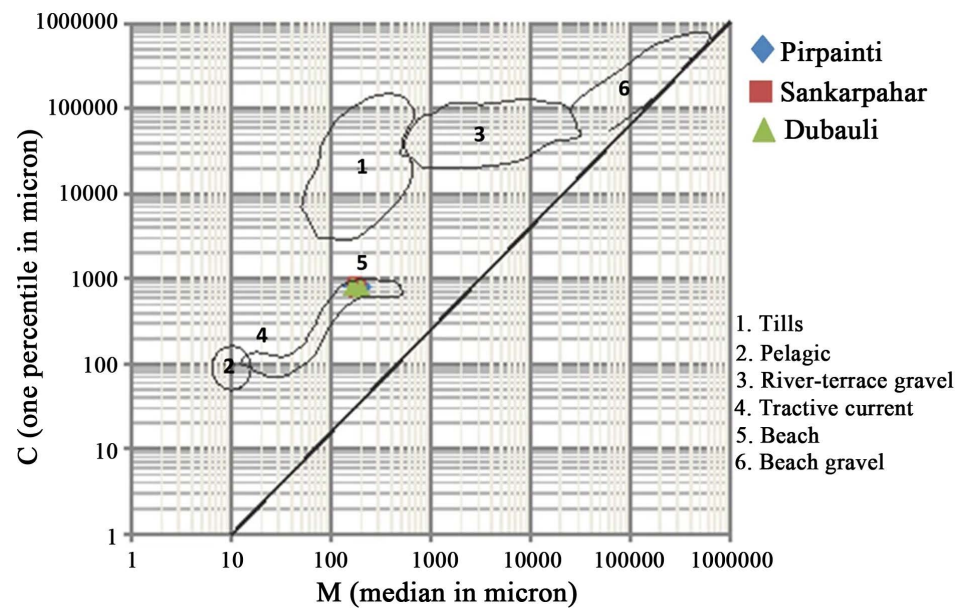

Figure 9. C-M plot showing depositional environment of the Rajmahal Inter-trappean sandstone. 


\section{Conclusion}

Grain size analysis of Rajmahal Inter-trappean has been carried out to study the characteristics of the sediments using the statistical parameters. These statistical parameters are further used to evaluate the environment in which they were deposited. The Rajmahal Inter-trappean sandstones show the dominance of fine grained particles. These sandstones are moderately sorted due to the wave activity in the beach environment. The samples are dominantly fine skewed which implies the dominance of fine sediments. Majority of samples are mesokurtic in nature that this reflects moderate maturity of the sand. Variation in the nature of the peak may be due to sorting activity done by waves which may lead to continuous addition of materials in various proportions. The Linear discriminant function dominantly confirms shallow marine environment and is reworked by beach process. The multigroup multivariant discriminant function V1 - V2 diagram shows dominance of beach deposits. Hence these sediments were mainly deposited in shallow marine environment by beach and wave processes. C-M pattern for Rajmahal Inter-trappean sandstone suggests transportation by rolling and suspension of sediments in beach environment.

\section{Conflicts of Interest}

The authors declare no conflicts of interest regarding the publication of this paper.

\section{References}

[1] Boggs Jr., S. (2009) Petrology of Sedimentary Rocks. 2nd Edition, Cambridge University Press, Cambridge. https://doi.org/10.1017/CBO9780511626487

[2] Edwards, A.C. (2001) Grain Size and Sorting in Modern Beach Sands. Journal of Coastal Research, 17, 38-52.

[3] Blott, S.J. and Pya, K. (2001) GRADSTAT: A Grain Size Distribution and Statistics Package for the Analysis of Unconsolidated Sediments. Earth Surface Process Landforms, 26, 1237-1248. https://doi.org/10.1002/esp.261

[4] Bakshi, A.K., Barman, R.R., Paul, D.K. and Farrar, E. (1987) Widespread Early Cretaceous Flood Basalt Volcanism in Eastern India: Geochemical Data from the Rajmahal-Bengal-Sylhet Traps. Chemical Geology, 63, 133-141. https://doi.org/10.1016/0009-2541(87)90080-5

[5] Dalrymple, G.B. and Lanphere, M.A. (1947) ${ }^{40} \mathrm{Ar} /{ }^{30} \mathrm{Ar}$ Spectra of Some Undisturbed Terrestrial Samples. Geochimica et Cosmochimica Acta, 38, 715-738. https://doi.org/10.1016/0016-7037(74)90146-X

[6] Madukwe, H.Y. (2016) Granulometric Analysis of the Sandstone Facies of the Ise Formation, Southwestern Nigeria. Journal of Multidisciplinary Engineering Science and Technology (JMEST), 3, 3909-3919.

[7] Kent, R.W., Pringle, M.S., Dietmar Müller, R., Saunders, A.D. and Ghose, N.C. (2002) ${ }^{40} \mathrm{Ar} /{ }^{39} \mathrm{Ar}$ Geochronology of the Rajmahal Basalts, India, and Their Relationship to the Kerguelen Plateau. Journal of Petrology, 43, 1141-1153. https://doi.org/10.1093/petrology/43.7.1141

[8] Ghose, N.C., Chatterjee, N. and Windley, B.F. (2017) Subaqueous Eruptive Phase of 
the Late Aaptian Rajmahal Volcanism India: Evidence from Volcaniclastic Rocks, Bentonite, Black Shales and Oolite. Geoscience Frontiers, 8, 809-822. https://doi.org/10.1016/j.gsf.2016.06.007

[9] Ghose, N.C. (1983) Geology, Tectonics and Evolution of Chottanagpur Granite Gneiss Complex, Eastern India. Recent Research in Geology 10, Hindustan Publishing Co., Delhi, 211-247.

[10] Chatterjee, N. and Ghose, N.C. (2011) Extensive Early Neoproterozoics High Grade Metamorphism in North Chottanagpur Gneissic Complex of the Central Indian Tectonic Zone. Gondwana Research, 20, 362-379. https://doi.org/10.1016/j.gr.2010.12.003

[11] Mukhopadhya, M., Verma, R.K. and Ashraf, M.H. (1986) Gravity Field and Structures of Rajmahal Hills: Examples of Paleo-Mesozoic Continental Margin in Eastern India. Tectonophysics, 131, 353-367. https://doi.org/10.1016/0040-1951(86)90182-4

[12] Ghose, N.C., Sing, S.P., Singh, R.N. and Mukherjee, D. (1996) Flow Stratigraphy of a Selected Sections of Rajmhal Basalts Eastern India. Journal of Southeast Asian Earth Sciences, 13, 83-93. https://doi.org/10.1016/0743-9547(96)00010-4

[13] Pascoe, E.H. (1975) A Manual of Geology of India and Burma. Government of India Publication, New Delhi, 1345-2130.

[14] Coffin, M.F., Pringle, M.S., Duncan, R.A., Gladczenko, T.P., Storeyr, M., Müller, D. and Gahagan, L.A. (2002) Kerguelen Hotspot Magma Output Since 130 Ma. Journal of Petrology, 43, 1121-1137. https://doi.org/10.1093/petrology/43.7.1121

[15] Kent, R.W., Saunders, A.D., Kempton, P.D. and Ghose, N.C. (1997) Rajmahal Basalts, Eastern India: Mantel Sources and Melts Distribution at a Volcanic Rifted Margin. American Geophysical Union, Geophysical Monograph, 100, 145-182.

[16] Storey, M., Kent, R.W., Saunders, A.D., Salters, V.J., Hergt, J., Whitechurch, H., Sevigny, J.H., Thirlwall, M.F., Leat, P., Ghose, N.C., Gifford, M., Schlich, R., et al. (1992) Lower Cretaceous Volcanic Rocks on Continental Margins and Their Relationship to the Kerguelen Plateau, Proceedings of the Ocean Drilling Program. Scientific Results, 120, 33-53. https://doi.org/10.2973/odp.proc.sr.120.118.1992

[17] Ghose, N.C. and Kent, R.W. (2003) The Rajmahal Basalts: A Review of Their Geology, Composition and Petrogenesis. Memoir, 53, 167-196.

[18] Ingram, R.L. (1971) Sieve Analysis. In: Carver, R.E, Ed., Procedures in Sedimentary Petrology, Wilson Interscience, New York, 49-68.

[19] Folk, R.L. and Ward, W. (1957) Brazos River Bar: A Study in the Significance of Grains-Size Parameters. Journal of Sedimentary Research, 27, 3-26. https://doi.org/10.1306/74D70646-2B21-11D7-8648000102C1865D

[20] Sahu B.K. (1964) Depositional Mechanism from the Size Analysis of Elastic Sediments. Journal of Sedimentary Petrology, 34, 73-83.

[21] Sahu, B.K. (1983) Multigroup Discrimination of Depositional Environments Using Size Distribution Statistics. Indian Journal of Earth Sciences, 10, 20-29.

[22] Reineck, H.E. and Singh, I.B. (1980) Depositional Sedimentary Environments. 2nd Edition, Springer, Berlin, 543 p. https://doi.org/10.1007/978-3-642-81498-3

[23] Pettijohn, F.J. (1984) Sedimentary Rocks. 3rd Edition, CBS Publ., New Delhi, 628 p.

[24] Lindholmn, R.C. (1987) A Practical Approach to Sedimentology. Springer, Berlin, 270 p. https://doi.org/10.1007/978-94-011-7683-5

[25] Sengupta, S.M. (1996) Introduction to Sedimentology. Oxford \& IBH Publishing Co., New Delhi, 305 p. 
[26] Passega, R. (1957) Texture as Characteristics of Clastic Deposition. American Association of Petroleum Geologists Bulletin No. 41, 1952-1984.

[27] Passega, R. (1964) Grain Size Representation by C-M Pattern as a Geological Tool. Journal of Sedimentary Petrology, 34, 830-847. https://doi.org/10.1306/74D711A4-2B21-11D7-8648000102C1865D

[28] Folk, R.L. (1966) A Review of Grain-Size Parameters. Sedimentology, 6, 73-93. https://doi.org/10.1111/j.1365-3091.1966.tb01572.x

[29] Friedman, G.M. (1961) Distinction between Dune, Beach and River Sands from Their Textural Characteristics. Journal of Sedimentary Petrology, 31, 514-529.

[30] Friedman, G.M. (1967) Dynamic Processes and Statistical Parameters Compared for Size Frequency Distribution of Beach and River Sands. Journal of Sedimentary Petrology, 37, 327-354.

[31] Moiola, R.J. and Weiser, D. (1968) Textural Parameters: An Evaluation. Journal of Sedimentary Petrology, 38, 45-53.

[32] Visher G.S. (1969) Grain Size Distributions and Depositional Processes. Journal of Sedimentary Petrology, 39, 1074-1106.

[33] Friedman, G.M. (1967) Dynamic Processes and Statistical Parameters Compared for Size Frequency Distribution of Beach and River Sands. Journal of Sedimentary Petrology, 37, 327-354.

[34] Moiola R.J. and Weiser, D. (1968) Textural Parameters: An Evaluation. Journal of Sedimentary Petrology, 38, 45-53.

https://doi.org/10.1306/74D718C5-2B21-11D7-8648000102C1865D

[35] Sahu, B.K. (1964) Environments of Deposition from the Size Analysis of Clastic Sediments. PhD Thesis, University of Wisconsin, Madison.

[36] Stewart, H.B. (1958) Sedimentary Reflections of Depositional Environment in San Miguel Lagoon, Baja California, Mexico. AAPG Bulletin, 42, 2576-2618. 